\title{
Effect of Whole Body Vibration on Obese Hypothyroid Postmenopausal Women
}

\author{
OMAR S. ABDEL-LATIF, M.Sc.*; MAGDA S. MORSY, Ph.D.* and HASSAN O. GHARIB, M.D.** \\ The Department of Physical Therapy for Woman's Health*, Faculty of Physical Therapy, Cairo University and \\ Department of Gynecology \& Obstetrics**, Faculty of Medicine, Cairo University
}

\begin{abstract}
Background: This study was conducted to determine the effect of whole body vibration on 30 obese hypothyroid postmenopausal women.

Aim of Study: The aim of this study was to investigate the effect of whole body vibration on hypothyroidism in postmenopausal women.

Material and Methods: Thirty obese postmenopausal women were participated in this study. They were referred from outpatient clinic of physical therapy department in Elshiekh Zayed Specialized Hospital. Their ages were ranged from (50-55) years old with a mean value $51.83 \pm 1.7$ years and their (BMI) was ranged from $(30-35) \mathrm{kg} / \mathrm{m}^{2}$ with a mean value $31.6 \pm 1.62 \mathrm{~kg} / \mathrm{m}^{2}$. All patients were clinically diagnosed as hypothyroidism and all of them were receiving hypothyroid medical treatment in the form of thyroxine tablets (2-3 tablets per day). All participants were randomly divided into two groups equal in number, control group (group A) and study group (group B). Patients in group (A) were treated by thyroxine tablets described by the physician and a low caloric diet program for 8 weeks, while patients in group (B) were treated by thyroxine tablets and the same low caloric diet program as group (A) in addition to performing a whole body vibration training machine for 40 minutes, 3 sessions per week for 8 weeks. The session of WBV was consisted of 40 minutes, started with low frequency $(20 \mathrm{HZ})$, then increased frequency gradually up to $100 \mathrm{~Hz}$ and then ended with low frequency $(20 \mathrm{HZ})$. All patients in both groups (A\&B) were evaluated by measuring body weight, Body mass index (BMI), Waist hip ratio (WHR), total cholesterol, triglycerides, highdensity lipoprotein, low-density lipoprotein, TSH, FT 3, FT4 before starting and after the end of the treatment program.
\end{abstract}

Results: The results showed a highly significant ( $p$-value $\leq 0.0001$ ) decrease in body weight, Body mass index, Waist hip ratio, total cholesterol, triglycerides, low-density lipoprotein and TSH hormone with a significant $(p$-value $\leq 0.0001)$ increase in high-density lipoprotein, FT 3 and FT 4 after treatment in both groups. Yet, these changes were more pronounced and statistically significant in the study group when compared to the control group.

Conclusion: It could be concluded that whole body vibration training combined with low caloric diet program with

Correspondence to: Dr. Omar S. Abdel-Latif, E-Mail: dr.omarsaid@hotmail.com thyroxine tablets is much better than using only a low caloric diet program with thyroxine tablets in treating obese postmenopausal women with hypothyroidism. Thus, whole body vibration training has a great and beneficial effect on hypothyroidism in obese postmenopausal women. It gives amazing results and noticeable changes.

Key Words: Whole body vibration - Hypothyroidism - Menopause-Obesity.

\section{Introduction}

THYROID gland is a butterfly-shaped organ located in the base of the neck. It releases hormones that control metabolism as the way the body uses energy. The thyroid hormones regulate vital body functions including breathing, heart rate, central and peripheral nervous systems, body weight, muscle strength, menstrual cycle, body temperature and cholesterol levels [1].

The thyroid gland is about 2-inches long and is located in front of the throat below the prominence of thyroid cartilage sometimes called Adam's apple. The thyroid has two sides called lobes that lie on either side of the windpipe and is usually connected by a band of thyroid tissue known as an isthmus. The gland is usually larger in women than men and increases in size during pregnancy [2].

The thyroid is part of the endocrine system, which is made up of glands that produce, store, and release hormones into the bloodstream so the hormones can reach the body's cells. The thyroid gland uses iodine from the foods to make two main hormones: Triiodothyronine (T 3 ) and Thyroxine (T4). The major form of thyroid hormone in the blood is thyroxine (T4) which has a longer halflife than T3. It is important that T 3 and T4 levels are neither too high nor too low. Both glands in the brain, the hypothalamus and the pituitary communicate to maintain $\mathrm{T} 3$ and $\mathrm{T} 4$ balance [3] 
Levels of serum thyroid hormones are tightly regulated by the hypothalamic-pituitary-thyroid axis. Thyroid-releasing hormone (TRH) is secreted by the hypothalamus and stimulates the release of thyroid-stimulating hormone (TSH) from the pituitary gland. Secreted thyroid hormone reaches the hypothalamus and the pituitary where it inhibits production and secretion of TRH and TSH, thereby establishing the hypothalamic-pituitary-thyroid axis. Both The pituitary gland and hypothalamus control the thyroid gland [4].

Hypothyroidism or underactive thyroid occurs when the thyroid gland doesn't make enough thyroid hormones to meet the body's needs. Without enough thyroid hormones, many of body functions slow down [5]. Hypothyroidism can occur at any age and gender but is most commonly seen in females during menopausal years. Females are 8 times more likely to be affected than males [6].

Symptoms commonly associated with hypothyroidism are often nonspecific. These include weight gain, fatigue, poor concentration, depression, diffuse muscle pain, and menstrual irregularities. Symptoms with high specificity for hypothyroidism include constipation, cold intolerance, dry skin, proximal muscle weakness, and hair thinning or loss [7].

Patients with hypothyroidism should be dependent on current medications. Treatment for hypothyroidism focuses on replacing the thyroid hormone in the body comes in the form of synthetic thyroid hormone thyroxin and one of the natural ways is by increasing salt-iodine in the patient's diet [8]. It is important to treat the whole body as a system rather than seeing individual parts working separately. Diet and lifestyle factors formed a key component in the overall treatment of a patient with thyroid diseases [9].

Menopause is the time in women's lives when menstrual period stops permanently, and they are no longer able to fertile. Menopause typically occurs between 49 and 52 years of age. Menopause is defined as the time when there has no menstrual periods for 12 consecutive months and no other biological or physiological cause can be identified. It may also be defined by a decrease in hormone production by the ovaries [10].

Symptoms may begin many years earlier. Also, some women may experience symptoms for months or years afterward including hot flashes, night sweats, mood swings and vaginal dryness. In the United States, the average age for the menopause is 51 [11]
The hormonal changes across the menopause substantially contribute to increased obesity which leads to additional physical and psychological morbidity. Obesity is a public health problem, with overweight individuals representing approximately $20 \%$ of the adult world population. Weight control has an essential role in postmenopausal health and should be considered early in the perimenopause to safeguard the quality of life of women. Weight loss through diet and increased physical activity has been shown to alleviate menopausal symptoms

In hypothyroidism, increased TSH and decrease in $\mathrm{T} 3$ and $\mathrm{T} 4$, results in increased of body weight and alteration of lipid profile. Hypothyroidism causes a weight increase together with a decrease in basal metabolic rate and energy homeostasis

Postmenopausal women are usually troubled by increasing weight and waist circumference caused by obesity and fat redistribution. This is mostly attributed to estrogen depletion though other factors such as chronological aging and decline in physical activity play a significant role

Excess body weight is one of the most common health and economic problems in the world. According to the assessments of the World Health Organization (WHO), nearly billion adults are overweight and at least 300 million were diagnosed with clinical obesity (BMI >_40) [15].

In the elderly, humans usually have reduced muscle mass and increased fat accumulation that can increase risk of developing cardiovascular metabolic disease. Although regular physical exercise helps delay or slows these age-related changes, it isn't always possible in older people due to a disability or risk of injury. Whole-body vibration (WBV) training may be considered as an alternative to physical activity particularly in the frail population. Aging is characterized by a gradual decline in muscle mass with a simultaneous increase in fat mass and waist circumference (obesity) [16]

Over the past decade, whole-body vibration (WBV) has become an increasingly popular training method among people to improve the performance and has therapeutic purposes in geriatric rehabilitation. In WBV training, vibration stimuli are delivered to the body via the vibration platform or chair. Vibrations stimuli may influence systemic hormone levels and tissue perfusion due to direct mechanical stimulation or as the result of altered neuromuscular activity [17]. 
Whole body vibration is applied through a vibrating platform on which a person stands for a certain period of time. Vibrating platforms currently marketed provide sinusoidal vibrations with amplitudes ranging from $<1$ to $15 \mathrm{~mm}$ and frequencies of oscillations ranging from 15 to $60 \mathrm{~Hz} 18$. This modality of training can improve physical capacity, hormonal productions, blood flow, lymphatic flow, bone mass, balance, proprioception, health related quality of life (HRQOL) in healthy subjects and increase the force of muscles in the short duration of time with less fatigue [19].

Whole body vibrations have been positively associated with substantial increases in hormone production, possibly through direct mechanical stimulation or enhanced biomolecular transport. The thyroid is filled with a gel-like substance that is the storage form of thyroid hormone. The gel releases hormones when the thyroid is vibrated, which is why massage therapists avoid throat massages for hyperthyroid patients. So, the thyroid is clearly affected by vibration [20] .

One of the advantages of the WBV is a short application time, ease of use and this technique could be a highly effective intervention for fall prevention in the elderly. Another important difference between traditional training methods and WBV is that there is only a minimum of loading. That is why WBV is ideal choice for people who have difficulty training due to aging, illness, disorders, weights or injury [21].

\section{Subjects and Methods}

Subjects:

Thirty obese postmenopausal women were participated in this study. They were referred from outpatient clinic of physical therapy department in Elshiekh Zayed Specialized Hospital during a period from January 2021 to April 2021. Their ages were ranged from (50-55) years old, and their (BMI) was ranged from (30-35) $\mathrm{kg} / \mathrm{m}^{2}$. All patients were clinically diagnosed as they have hypothyroidism and the all of them were receiving hypothyroid medical treatment in the form of thyroxine tablets (2-3 tablets per day). All patients were free from any cardiovascular diseases, musculoskeletal disorders, neurological diseases, mental disorders, chest diseases, heart diseases, diabetes, hypertension, renal failure or positive signs of covid-19. All patients were randomly divided into two equal groups (A\&B).

Group A (control group): 15 patients who were treated by thyroxine tablets and followed a low caloric diet program for 8 weeks.
Group B (study group): 15 patients who were treated by thyroxine tablets and followed a low caloric diet program and performed whole body vibration training for 40 minutes, 3 sessions per week for 8 weeks.

Table (1): Physical characteristics of patients of both groups (A\&B).

\begin{tabular}{llcccc}
\hline Variables & $\begin{array}{c}\text { Control } \\
\text { Group (A) }\end{array}$ & $\begin{array}{c}\text { Study } \\
\text { Group (B) }\end{array}$ & $\begin{array}{c}t \text { - } \\
\text { value }\end{array}$ & $\begin{array}{c}p \text { - } \\
\text { value }\end{array}$ & $\begin{array}{c}\text { Signi- } \\
\text { ficance }\end{array}$ \\
\hline Age (years) & $51.73 \pm 1.53$ & $51.93 \pm 1.87$ & 0.32 & 0.751 & NS \\
BMI $\left(\mathrm{kg} / \mathrm{m}^{2}\right)$ & $32.28 \pm 1.6$ & $32.95 \pm 1.64$ & 1.14 & 0.264 & NS \\
\hline
\end{tabular}

\section{Materials:}

\section{1- For Evaluation:}

A- Weight-height scale: It was used to measure the body weight and height for each patient in both groups (A\&B) before and after the treatment course to calculate the patient's body mass index.

$$
\mathrm{BMI}=\frac{\text { Weight }(\mathrm{kg})}{\text { Square of body height }\left(\mathrm{m}^{2}\right)}=\mathrm{kg} / \mathrm{m}^{2}
$$

B- Tape measurement: It was used to measure waist circumference (WC) \& hip circumference (HC) to measure waist-hip ratio for each patient in both groups (A\&B) before and after the treatment course. WHR is calculated as waist circumference divided by hip circumference (W $\div \mathrm{H})$.

C- Blood sample analysis: A sample of blood from each patient in both groups (A\&B) before and after the treatment course was analyzed in the laboratory to measure levels of TSH, FT 3, FT4 TC, TG, HDL and LDL in blood.

\section{2- For treatment:}

A- Whole Body Vibration (WBV). It was used by each patient in study group (B) to perform the treatment program for 40 minutes, 3 sessions per week for 8 weeks.

B- A stop watch: It was used to detect time of each treatment session for all patients in study group (B).

C- A specific diet program designed by a nutritionist for 8 weeks for each patient in both groups $(\mathrm{A} \& \mathrm{~B})$.

\section{Procedures:}

\section{1- Evaluation procedure:}

Before engagement to the study, all data of each patient were recorded in a recording data 
sheet. Detailed medical and physical conditions and current medication were carefully taken to confirm that all patients are suitable for the study. The weight and height were measured for each patient before and after the treatment course to calculate BMI in both groups. Also, waist and hip circumferences were measured for each patient before and after the treatment course to calculate Waist-Hip Ratio. Blood samples were collected with the help of professional technicians to measure thyroid hormones level (TSH, FT3, FT4) and Lipid profiles (serum Cholesterol, TG, LDL, HDL) before and after training program in both groups (A\&B).

\section{2- Treatment procedures:}

For group (A): It was consisted of 15 obese hypothyroid postmenopausal women. BMI, serum thyroid hormones and lipid profiles were measured before starting the program. Patients in this group received only their medical treatment of hypothyroidism (thyroxine tab) 2-3 daily and followed a low calorie diet program for 8 weeks. At the end of the eighth week, Serum thyroid hormones and lipid profiles were measured again. According to the recommendation of health care professionals, Low caloric diet should contain:

- Vegetables as Veggies stabilize blood sugar and are low in calories, salads, raw veggies, and vegetable soups.

- Non starchy vegetables as cauliflower, cabbage, spinach, eggplants and okra.

- Fruits with low sugar content as orange, guava, apples, grape-fruits, pineapple, apricot and mandarin.

- Food that contains fibers as broccoli, carrot, cucumber, green \& colored peppers, lettuce and tomato.

- Low fat dairy products such as skimmed milk, low fat yogurt, karesh cheese.

- White meat of poultry white meat of turkey, skinless chicken breasts, fish and tuna.

- Drink plenty of water (8 glasses of water daily).

- Plan healthy snacks. Stock up on fruit, nuts, yogurts and fresh sugarless juices.

The caloric intake should be ranged from 1200$1600 \mathrm{Kcal}$ per day not more to achieve weight reduction about $1-2 \mathrm{~kg} /$ week. The intensity of moderate exercises should be $70 \%$ not more.

For group (B): It was consisted of 15 obese hypothyroid postmenopausal women, Each patient was treated by thyroxine tablets described for her by the physician and the same low caloric diet program as group (A) in addition to performing a whole body vibration training machine for 40 minutes, 3 sessions per week for 8 weeks. The session of WBV consisted of 40 minutes, start with low frequency $(20 \mathrm{HZ})$, then increase frequency gradually up to $100 \mathrm{~Hz}$, then end the session with low frequency $(20 \mathrm{HZ})$.

\section{Statistical analysis:}

Data were summarized using the arithmetic mean, standard deviation (SD) and the percentage of changes.

The student's $t$-test used for comparison of data collected from both groups before and after the end of the treatment program.

\section{Results}

The mean values of the body weight $(\mathrm{kg})$ for patients of the control group (A) before starting the treatment was $80.43 \pm 4.55$, it was decreased to $69.22 \pm 4.97$ after the treatment, with a percentage of decrease equal $13.93 \%$. In patients of the study group (B), the mean values of body weight $(\mathrm{kg})$ was $83.73 \pm 4.85$ before treatment, and it was decreased to $57.22 \pm 4.78$ after the treatment, with a percentage of decrease equal $31.66 \%$ as shown in Table (2) and Fig (1).

By comparing the mean values of body weight before starting and after the end of the treatment of both groups (A\&B), a statistical significant $(p \leq 0.0001)$ decrease was observed in both group following the treatment, but this decrease was more pronounced and statistically significant in the study group when compared to the control group.

This means that, low caloric diet program with WBV training was much better than low caloric diet program only for treating obesity and hypothyroidism in postmenopausal women.

Table (2): Showed mean values of body weight $(\mathrm{kg})$ pre \& post-treatment for the control and study groups $(\mathrm{A} \& \mathrm{~B})$

\begin{tabular}{|c|c|c|c|c|}
\hline \multirow{3}{*}{ Variables } & \multicolumn{4}{|c|}{ Body weight (kg) } \\
\hline & \multicolumn{2}{|c|}{$\begin{array}{c}\text { Control } \\
\text { Group (A) }\end{array}$} & \multicolumn{2}{|c|}{$\begin{array}{c}\text { Study } \\
\text { Group (B) }\end{array}$} \\
\hline & $\begin{array}{c}\text { Pre- } \\
\text { treatment }\end{array}$ & $\begin{array}{l}\text { Post- } \\
\text { treatment }\end{array}$ & $\begin{array}{c}\text { Pre- } \\
\text { treatment }\end{array}$ & $\begin{array}{l}\text { Post- } \\
\text { treatment }\end{array}$ \\
\hline Mean \pm SD & $80.43 \pm 4.55$ & $69.22 \pm 4.97$ & $83.73 \pm 4.85$ & $57.22 \pm 4.78$ \\
\hline MD & \multicolumn{2}{|c|}{11.21} & \multicolumn{2}{|c|}{26.51} \\
\hline$\%$ of decrease & \multicolumn{2}{|c|}{$13.93 \%$} & \multicolumn{2}{|c|}{$31.66 \%$} \\
\hline$t$-value & \multicolumn{2}{|c|}{9.11} & \multicolumn{2}{|c|}{11.52} \\
\hline$p$-value & \multicolumn{2}{|c|}{0.0001} & \multicolumn{2}{|c|}{0.0001} \\
\hline
\end{tabular}




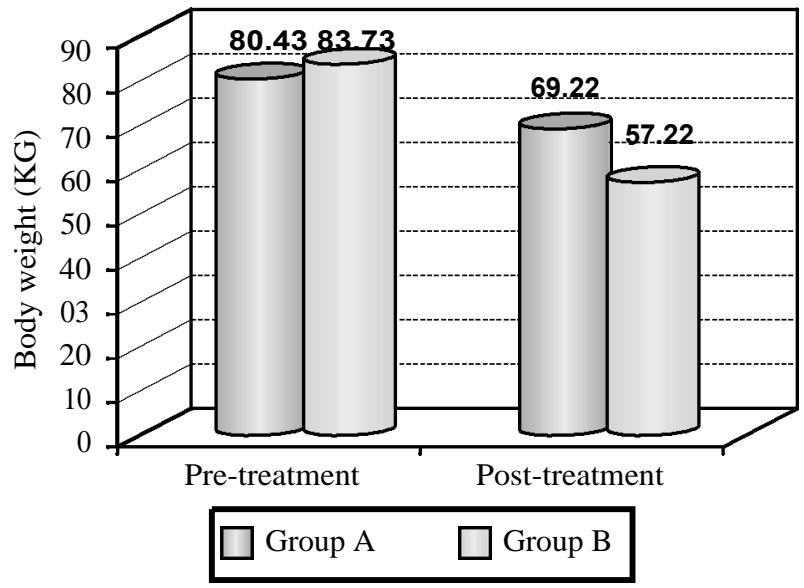

Fig. (1): Illustrates mean values of body weight $(\mathrm{Kg})$ pre and post-treatment course for both groups (A\&B).

The mean values of the body mass index (BMI) before and after the treatment program of both groups $(\mathrm{A} \& \mathrm{~B})$ were compared and statistical significant $(p \leq 0.0001)$ decrease was observed in both groups following the treatment. Yet, this decrease was pronounced and statistically significant $(p \leq 0.0001)$ in the study group when compared to the control group as observed in Table (3) and Fig. (2).

Table (3): Showed mean values of body mass index $\left(\mathrm{kg} / \mathrm{m}^{2}\right)$ pre $\&$ post-treatment for the control and study groups $(\mathrm{A} \& \mathrm{~B})$.

\begin{tabular}{|c|c|c|c|c|}
\hline \multirow{3}{*}{ Variables } & \multicolumn{4}{|c|}{ Body mass index (BMI) } \\
\hline & \multicolumn{2}{|c|}{$\begin{array}{c}\text { Control } \\
\text { Group (A) }\end{array}$} & \multicolumn{2}{|c|}{$\begin{array}{c}\text { Study } \\
\text { Group (B) }\end{array}$} \\
\hline & $\begin{array}{c}\text { Pre- } \\
\text { treatment }\end{array}$ & $\begin{array}{c}\text { Post- } \\
\text { treatment }\end{array}$ & $\begin{array}{c}\text { Pre- } \\
\text { treatment }\end{array}$ & $\begin{array}{c}\text { Post- } \\
\text { treatment }\end{array}$ \\
\hline Mean $\pm \mathrm{SD}$ & $34.07 \pm 1.6$ & $30.19 \pm 1.49$ & $32.95 \pm 1.64$ & $22.18 \pm 1.13$ \\
\hline $\mathrm{MD}$ & \multicolumn{2}{|c|}{3.38} & \multicolumn{2}{|c|}{10.77} \\
\hline$\%$ of decrease & \multicolumn{2}{|c|}{$11.38 \%$} & \multicolumn{2}{|c|}{$32.6 \%$} \\
\hline$t$-value & \multirow{2}{*}{\multicolumn{2}{|c|}{8.92}} & \multicolumn{2}{|c|}{11.08} \\
\hline$p$-value & & & \multicolumn{2}{|c|}{0.0001} \\
\hline
\end{tabular}

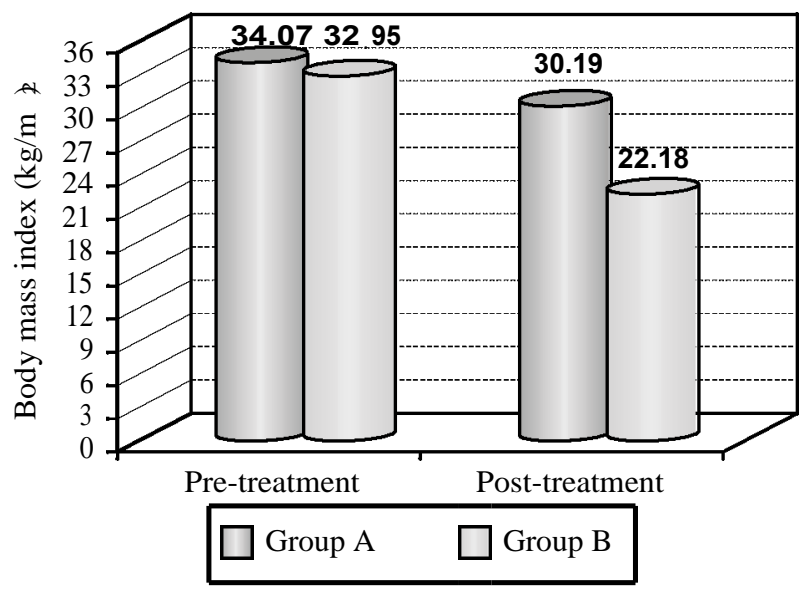

Fig. (2): Illustrates mean value of body mass index (BMI) $\mathrm{kg} / \mathrm{m}^{2}$ pre and post-treatment course for both groups $(\mathrm{A} \& \mathrm{~B})$.
The mean values of waist-hip ratio $(\mathrm{cm})$ before and after the treatment program of both groups $(A \& B)$ were compared and statistical significant $(p \leq 0.0001)$ decrease was observed in both groups following the treatment. Yet, this decrease was pronounced and statistically significant $(p \leq 0.0001)$ in the study group when compared to the control group as observed in Table (4) and Fig. (3).

Table (4): Showed mean values of waist-hip ratio $(\mathrm{cm})$ pre \& post-treatment for the control and study groups (A\&B).

\begin{tabular}{|c|c|c|c|c|}
\hline \multirow{3}{*}{ Variables } & \multicolumn{4}{|c|}{ Waist hip ratio (WHR) } \\
\hline & \multicolumn{2}{|c|}{ Control Group (A) } & \multicolumn{2}{|c|}{ Study Group (B) } \\
\hline & $\begin{array}{c}\text { Pre- } \\
\text { treatment }\end{array}$ & $\begin{array}{l}\text { Post- } \\
\text { treatment }\end{array}$ & $\begin{array}{c}\text { Pre- } \\
\text { treatment }\end{array}$ & $\begin{array}{c}\text { Post- } \\
\text { treatment }\end{array}$ \\
\hline Mean \pm SD & $0.81 \pm 0.03$ & $0.78 \pm 0.03$ & $0.78 \pm 0.04$ & $0.3 \pm 0.03$ \\
\hline $\mathrm{MD}$ & \multicolumn{2}{|c|}{0.03} & \multicolumn{2}{|c|}{0.48} \\
\hline$\%$ of decrease & \multicolumn{2}{|c|}{$1.23 \%$} & \multicolumn{2}{|c|}{$61.53 \%$} \\
\hline$t$-value & \multicolumn{2}{|c|}{5.96} & \multicolumn{2}{|c|}{8.26} \\
\hline$p$-value & \multicolumn{2}{|c|}{0.0001} & \multicolumn{2}{|c|}{0.0001} \\
\hline
\end{tabular}

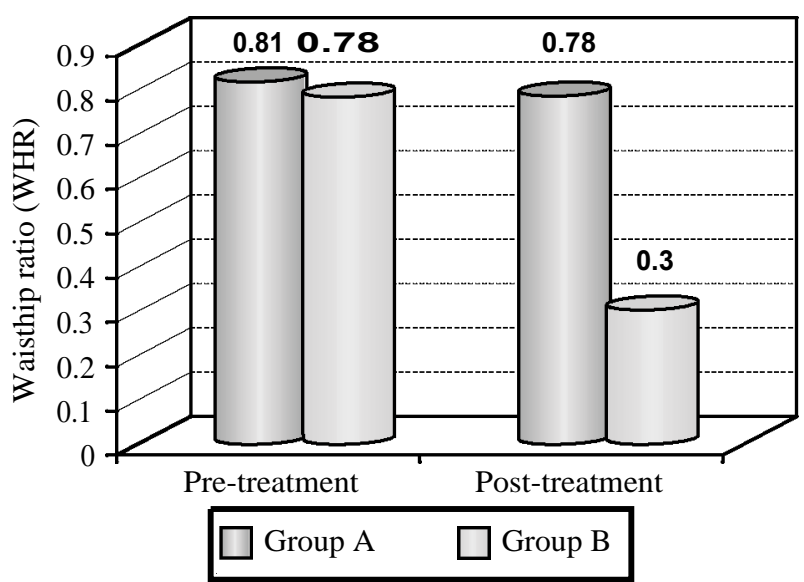

Fig. (3): Illustrates mean waist hip ratio (WHR) $\mathrm{cm}$ pre and post-treatment course for both groups (A\&B).

The mean values of total cholesterol (TC) before and after the treatment program of both groups $(A \& B)$ were compared and statistical significant $(p \leq 0.0001)$ decrease was observed in both groups following the treatment. Yet, this decrease was pronounced and statistically significant $(p \leq 0.0001)$ in the study group when compared to the control group as observed in Table (5) and Fig. (4).

Table (5): Showed mean values of total cholesterol (TC) pre \& post-treatment for the control and study groups $(\mathrm{A} \& \mathrm{~B})$

\begin{tabular}{|c|c|c|c|c|}
\hline \multirow{3}{*}{ Variables } & \multicolumn{4}{|c|}{ Total cholesterol (TC) $\mathrm{mg} / \mathrm{dL}$} \\
\hline & \multicolumn{2}{|c|}{ Control Group (A) } & \multicolumn{2}{|c|}{ Study Group (B) } \\
\hline & $\begin{array}{c}\text { Pre- } \\
\text { treatment }\end{array}$ & $\begin{array}{l}\text { Post- } \\
\text { treatment }\end{array}$ & $\begin{array}{c}\text { Pre- } \\
\text { treatment }\end{array}$ & $\begin{array}{l}\text { Post- } \\
\text { treatment }\end{array}$ \\
\hline Mean $\pm \mathrm{SD}$ & \multicolumn{2}{|c|}{$250.76 \pm 3.94230 .20 \pm 4.05$} & $245.11 \pm 3.78$ & $211.39 \pm 6.41$ \\
\hline MD & \multicolumn{2}{|c|}{20.56} & \multicolumn{2}{|c|}{33.72} \\
\hline$\%$ of decrease & \multicolumn{2}{|c|}{$8.19 \%$} & \multicolumn{2}{|c|}{$13.75 \%$} \\
\hline$t$-value & \multicolumn{2}{|c|}{20.5} & \multicolumn{2}{|c|}{14.37} \\
\hline$p$-value & \multicolumn{2}{|c|}{0.0001} & \multicolumn{2}{|c|}{0.0001} \\
\hline
\end{tabular}




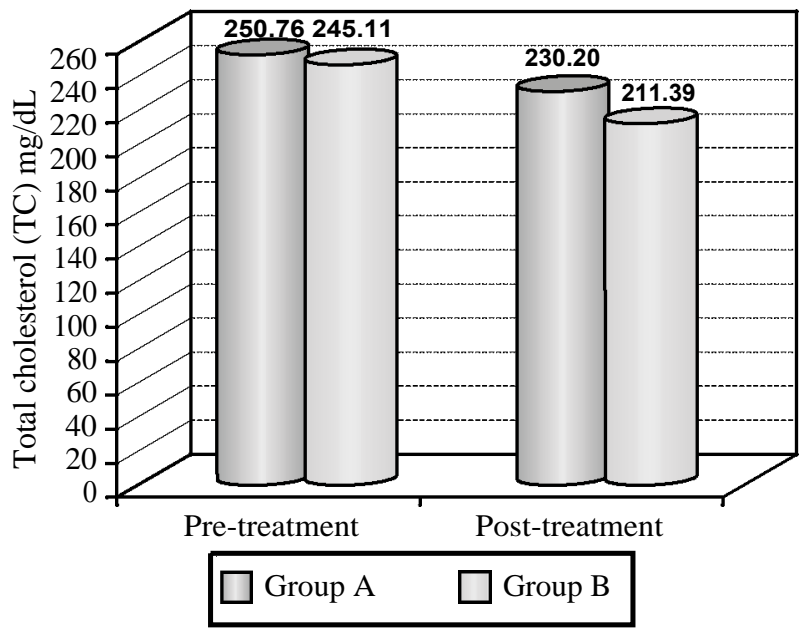

Fig. (4): Illustrates mean values of total cholesterol (TC) $\mathrm{mg} / \mathrm{dL}$ pre and post-treatment course for both groups $(\mathrm{A} \& \mathrm{~B})$.

The mean values of triglycerides (TG) before and after the treatment program of both groups $(A \& B)$ were compared and statistical significant $(p \leq 0.0001)$ decrease was observed in both groups following the treatment. Yet, this decrease was pronounced and statistically significant $(p \leq 0.0001)$ in the study group when compared to the control group as observed in Table (5) and Fig. (4).

Table (6): Showed mean values of triglycerides (TG) pre \& post-treatment for the control and study groups (A\&B).

\begin{tabular}{|c|c|c|c|c|}
\hline \multirow{3}{*}{ Variables } & \multicolumn{4}{|c|}{ Triglycerides (TG) mg/dL } \\
\hline & \multicolumn{2}{|c|}{$\begin{array}{c}\text { Control } \\
\text { Group (A) }\end{array}$} & \multicolumn{2}{|c|}{$\begin{array}{c}\text { Study } \\
\text { Group (B) }\end{array}$} \\
\hline & $\begin{array}{c}\text { Pre- } \\
\text { treatment }\end{array}$ & $\begin{array}{c}\text { Post- } \\
\text { treatment }\end{array}$ & $\begin{array}{c}\text { Pre- } \\
\text { treatment }\end{array}$ & $\begin{array}{c}\text { Post- } \\
\text { treatment }\end{array}$ \\
\hline Mean \pm SD & $218.41 \pm 4.88$ & $193.40 \pm 5.02$ & $224.17 \pm 4.9$ & $181.4 \pm 3.16$ \\
\hline & 25.0 & & 42.7 & \\
\hline$\%$ of decrease & 11.4 & & 19. & $07 \%$ \\
\hline$t$-value & 20.6 & & 28.8 & \\
\hline$p$-value & 0.00 & & 0.00 & \\
\hline
\end{tabular}

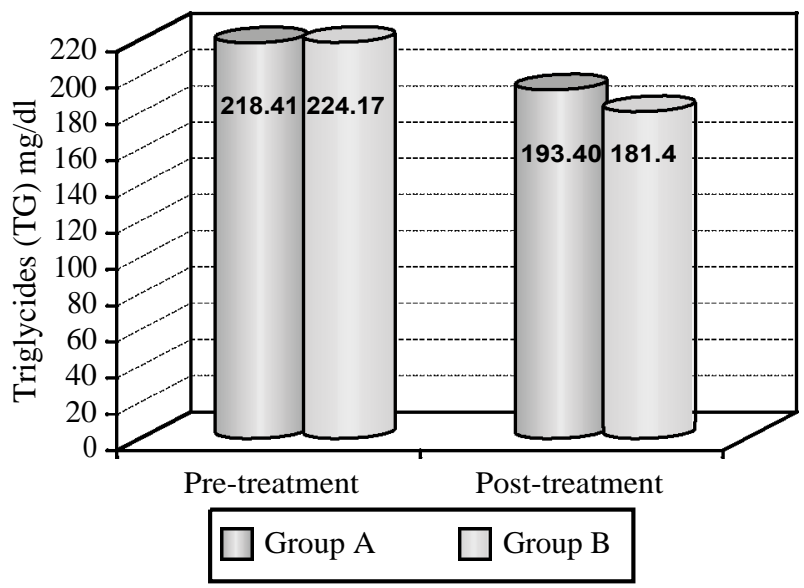

Fig. (5): Illustrates mean values of Triglycerides (TG) mg/dL pre and post-treatment course for both groups (A\&B).
The mean values of High density Lipoprotein (HDL) before and after the treatment program of both groups $(\mathrm{A} \& \mathrm{~B})$ were compared and statistical significant $(p \leq 0.0001)$ increase was observed in both groups following the treatment. Yet, this increase was pronounced and statistically significant $(p \leq 0.0001)$ in the study group when compared to the control group as observed in Table (7) and Fig. (6).

Table (7): Showed mean values of High density Lipoprotein (HDL) $(\mathrm{mg} / \mathrm{dL})$ pre \& post-treatment for the control and study groups $(\mathrm{A} \& \mathrm{~B})$.

\begin{tabular}{|c|c|c|c|c|}
\hline \multirow{3}{*}{ Variables } & \multicolumn{4}{|c|}{ High density Lipoprotein (HDL) (mg/dL) } \\
\hline & \multicolumn{2}{|c|}{$\begin{array}{c}\text { Control } \\
\text { Group (A) }\end{array}$} & \multicolumn{2}{|c|}{$\begin{array}{c}\text { Study } \\
\text { Group (B) }\end{array}$} \\
\hline & $\begin{array}{c}\text { Pre- } \\
\text { treatment }\end{array}$ & $\begin{array}{c}\text { Post- } \\
\text { treatment }\end{array}$ & $\begin{array}{c}\text { Pre- } \\
\text { treatment }\end{array}$ & $\begin{array}{c}\text { Post- } \\
\text { treatment }\end{array}$ \\
\hline Mean \pm SD & $43.07 \pm 4.03$ & $49.6 \pm 4.49$ & $45.27 \pm 4.5$ & $64.24 \pm 4.36$ \\
\hline MD & \multicolumn{2}{|c|}{6.53} & \multicolumn{2}{|c|}{23.19} \\
\hline$\%$ of decrease & \multicolumn{2}{|c|}{$15.16 \%$} & \multicolumn{2}{|c|}{$56.49 \%$} \\
\hline$t$-value & \multicolumn{2}{|c|}{14.12} & \multicolumn{2}{|c|}{24.2} \\
\hline$p$-value & \multicolumn{2}{|c|}{0.0001} & \multicolumn{2}{|c|}{0.0001} \\
\hline
\end{tabular}

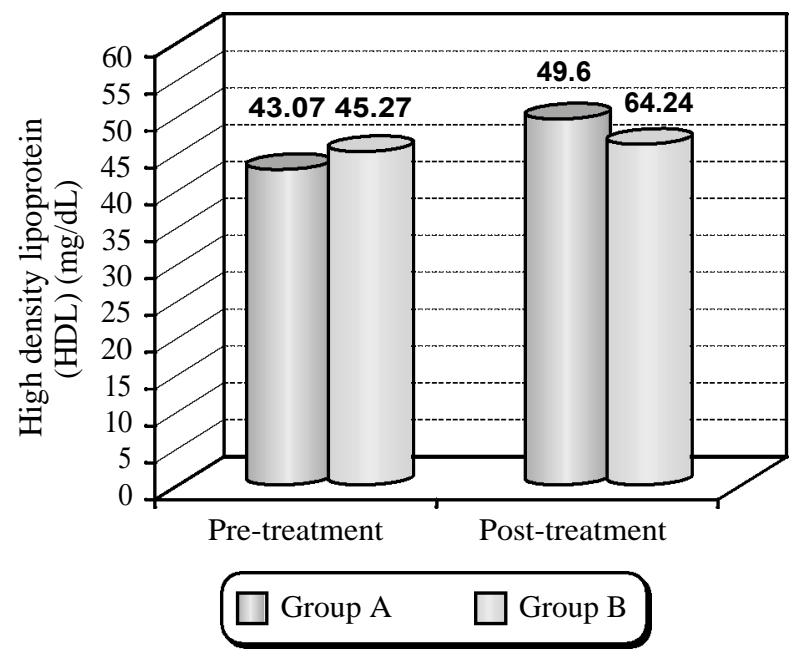

Fig. (6): Illustrates mean values of high density Lipoprotein (HDL) $(\mathrm{mg} / \mathrm{dL})$ pre and post-treatment course for both groups $(\mathrm{A} \& \mathrm{~B})$.

The mean values of Low density Lipoprotein (LDL) before and after the treatment program of both groups $(\mathrm{A} \& \mathrm{~B})$ were compared and statistical significant $(p \leq 0.0001)$ decrease was observed in both groups following the treatment. Yet, this decrease was pronounced and statistically significant $(p \leq 0.0001)$ in the study group when compared to the control group as observed in Table (8) and Fig. (7). 
Table (8): Showed mean values of Low density Lipoprotein $(\mathrm{LDL})(\mathrm{mg} / \mathrm{dL})$ pre \& post-treatment for the control and study groups $(\mathrm{A} \& \mathrm{~B})$.

\begin{tabular}{|c|c|c|c|c|}
\hline \multirow{3}{*}{ Variables } & \multicolumn{4}{|c|}{ Low density Lipoprotein (LDL) (mg/dL) } \\
\hline & \multicolumn{2}{|c|}{$\begin{array}{c}\text { Control } \\
\text { Group (A) }\end{array}$} & \multicolumn{2}{|c|}{$\begin{array}{c}\text { Study } \\
\text { Group (B) }\end{array}$} \\
\hline & $\begin{array}{c}\text { Pre- } \\
\text { treatment }\end{array}$ & $\begin{array}{c}\text { Post- } \\
\text { treatment }\end{array}$ & $\begin{array}{c}\text { Pre- } \\
\text { treatment }\end{array}$ & $\begin{array}{c}\text { Post- } \\
\text { treatment }\end{array}$ \\
\hline Mean \pm SD & $168.8 \pm 5.53$ & $150.33 \pm 6.96$ & $169.5 \pm 5.53$ & $122.09 \pm 8.06$ \\
\hline MD & \multicolumn{2}{|c|}{18.47} & \multicolumn{2}{|c|}{47.41} \\
\hline$\%$ of decrease & \multicolumn{2}{|c|}{$10.94 \%$} & \multicolumn{2}{|c|}{$27.97 \%$} \\
\hline$t$-value & \multicolumn{2}{|c|}{16.8} & \multicolumn{2}{|c|}{11.02} \\
\hline$p$-value & \multicolumn{2}{|c|}{0.0001} & \multicolumn{2}{|c|}{0.0001} \\
\hline
\end{tabular}

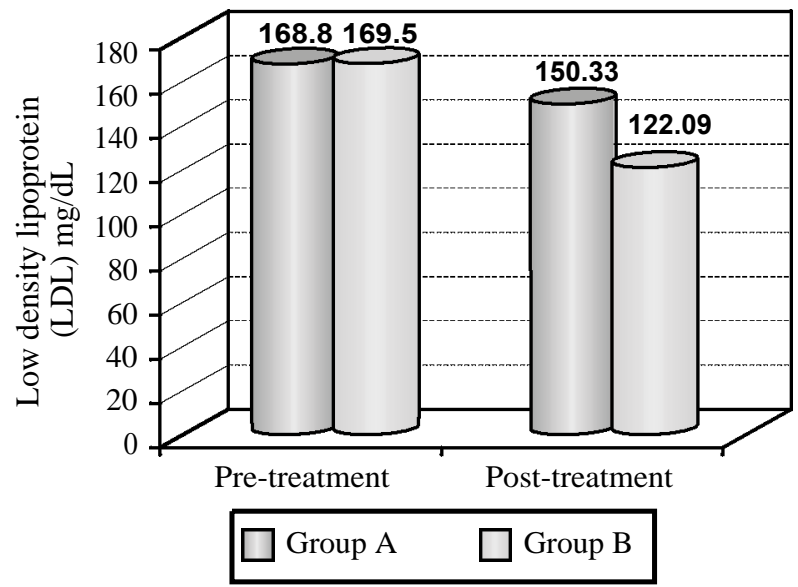

Fig. (7): Illustrates mean values of low density Lipoprotein (LDL) $(\mathrm{mg} / \mathrm{dL})$ pre and post-treatment course for both groups $(\mathrm{A} \& \mathrm{~B})$.

The mean values of Thyroid stimulating hormone (TSH) before and after the treatment program of both groups (A\&B) were compared and statistical significant $(p \leq 0.0001)$ decrease was observed in both groups following the treatment. Yet, this decrease was pronounced and statistically significant $(p \leq 0.0001)$ in the study group when compared to the control group as observed in Table (9) and Fig. (8).

Table (9): Showed mean values of Thyroid stimulating hormone (TSH) $(\mathrm{mu} / \mathrm{L})$ pre \& post-treatment for the control and study groups $(\mathrm{A} \& \mathrm{~B})$.

\begin{tabular}{|c|c|c|c|c|}
\hline \multirow{3}{*}{ Variables } & \multicolumn{4}{|c|}{ Thyroid stimulating hormone (TSH) $\mathrm{mu} / \mathrm{L}$} \\
\hline & \multicolumn{2}{|c|}{$\begin{array}{c}\text { Control } \\
\text { Group (A) }\end{array}$} & \multicolumn{2}{|c|}{$\begin{array}{c}\text { Study } \\
\text { Group (B) }\end{array}$} \\
\hline & $\begin{array}{c}\text { Pre- } \\
\text { treatment }\end{array}$ & $\begin{array}{c}\text { Post- } \\
\text { treatment }\end{array}$ & $\begin{array}{c}\text { Pre- } \\
\text { treatment }\end{array}$ & $\begin{array}{c}\text { Post- } \\
\text { treatment }\end{array}$ \\
\hline Mean \pm SD & $3.5 \pm 0.57$ & $3.09 \pm 0.57$ & $3.82 \pm 0.5$ & $2.1 \pm 0.53$ \\
\hline MD & \multicolumn{2}{|c|}{0.41} & \multicolumn{2}{|c|}{1.72} \\
\hline$\%$ of decrease & \multicolumn{2}{|c|}{$11.71 \%$} & \multicolumn{2}{|c|}{$45.02 \%$} \\
\hline$t$-value & \multicolumn{2}{|c|}{12.76} & \multicolumn{2}{|c|}{12.64} \\
\hline$p$-value & \multicolumn{2}{|c|}{0.0001} & \multicolumn{2}{|c|}{0.0001} \\
\hline
\end{tabular}

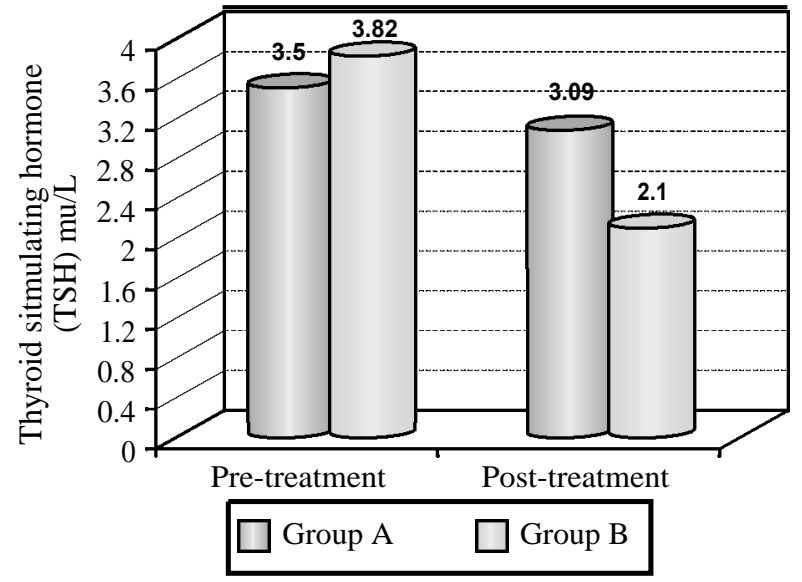

Fig. (8): Illustrates mean values of thyroid stimulating hormone $(\mathrm{TSH})(\mathrm{mu} / \mathrm{L})$ pre and post-treatment course for both groups (A\&B).

The mean values of Free Triiodothyronine (FT 3) before and after the treatment program of both groups (A\&B) were compared and statistical significant $(p \leq 0.0001)$ increase was observed in both groups following the treatment. Yet, this increase was pronounced and statistically significant ( $p \leq$ $0.0001)$ in the study group when compared to the control group as observed in Table (10) \& Fig. (9).

Table (10): Showed mean values of free triiodothyronine (FT3) $\mathrm{n} \mathrm{mol} / \mathrm{L}$ pre \& post-treatment for the control and study groups (A\&B).

\begin{tabular}{|c|c|c|c|c|}
\hline \multirow{3}{*}{ Variables } & \multicolumn{4}{|c|}{ Free triiodothyronine $(\mathrm{FT} 3) \mathrm{n} \mathrm{mol} / \mathrm{L}$} \\
\hline & \multicolumn{2}{|c|}{$\begin{array}{c}\text { Control } \\
\text { Group (A) }\end{array}$} & \multicolumn{2}{|c|}{$\begin{array}{c}\text { Study } \\
\text { Group (B) }\end{array}$} \\
\hline & $\begin{array}{c}\text { Pre- } \\
\text { treatment }\end{array}$ & $\begin{array}{c}\text { Post- } \\
\text { treatment }\end{array}$ & $\begin{array}{c}\text { Pre- } \\
\text { treatment }\end{array}$ & $\begin{array}{c}\text { Post- } \\
\text { treatment }\end{array}$ \\
\hline Mean \pm SD & $2.32 \pm 0.4$ & $2.67 \pm 0.39$ & $2.70 \pm 0.38$ & $3.94 \pm 0.4$ \\
\hline & \multicolumn{2}{|c|}{0.35} & \multicolumn{2}{|c|}{1.24} \\
\hline$\%$ of decrease & \multirow{2}{*}{\multicolumn{2}{|c|}{$\begin{array}{l}15.08 \% \\
11.39\end{array}$}} & \multicolumn{2}{|c|}{$45.92 \%$} \\
\hline$t$-value & & & & \\
\hline$p$-value & \multicolumn{2}{|c|}{0.0001} & \multicolumn{2}{|c|}{$\begin{array}{l}19.3 / \\
0.0001\end{array}$} \\
\hline
\end{tabular}

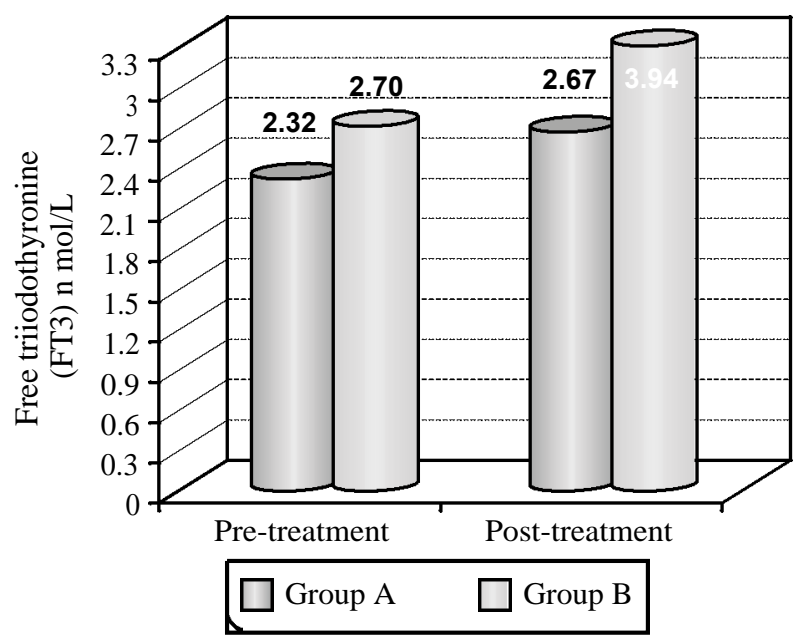

Fig. (9): Illustrates mean values of free triiodothyronine (FT 3 ) $\mathrm{n} \mathrm{mol} / \mathrm{L}$ pre and post-treatment course for both groups (A\&B). 
The mean values of Free Thyroxine hormone (FT4) before and after the treatment program of both groups $(\mathrm{A} \& \mathrm{~B})$ were compared and statistical significant $(p \leq 0.0001)$ increase was observed in both groups following the treatment. Yet, this increase was pronounced and statistically significant $(p \leq 0.0001)$ in the study group when compared to the control group as observed in Table (11) and Fig. (10).

Table (11): Showed mean values of free thyroxine hormone (FT4) $\mathrm{n} \mathrm{mol} / \mathrm{L}$ pre\& post-treatment for the control and study groups (A\&B).

\begin{tabular}{|c|c|c|c|c|}
\hline \multirow{3}{*}{ Variables } & \multicolumn{4}{|c|}{ Free thyroxine $(\mathrm{FT} 4) \mathrm{n} \mathrm{mol} / \mathrm{L}$} \\
\hline & \multicolumn{2}{|c|}{$\begin{array}{c}\text { Control } \\
\text { Group (A) }\end{array}$} & \multicolumn{2}{|c|}{$\begin{array}{c}\text { Study } \\
\text { Group (B) }\end{array}$} \\
\hline & $\begin{array}{c}\text { Pre- } \\
\text { treatment }\end{array}$ & $\begin{array}{c}\text { Post- } \\
\text { treatment }\end{array}$ & $\begin{array}{c}\text { Pre- } \\
\text { treatment }\end{array}$ & $\begin{array}{c}\text { Post- } \\
\text { treatment }\end{array}$ \\
\hline Mean \pm SD & $1.15 \pm 0.14$ & $1.42 \pm 0.13$ & $1.09 \pm 0.27$ & $1.97 \pm 0.1$ \\
\hline MD & \multicolumn{2}{|c|}{0.27} & \multicolumn{2}{|c|}{0.88} \\
\hline$\%$ of decrease & \multicolumn{2}{|c|}{$23.47 \%$} & \multicolumn{2}{|c|}{$80.73 \%$} \\
\hline$t$-value & \multicolumn{2}{|c|}{8.71} & \multicolumn{2}{|c|}{5.19} \\
\hline$p$-value & \multicolumn{2}{|c|}{0.0001} & \multicolumn{2}{|c|}{0.0001} \\
\hline
\end{tabular}

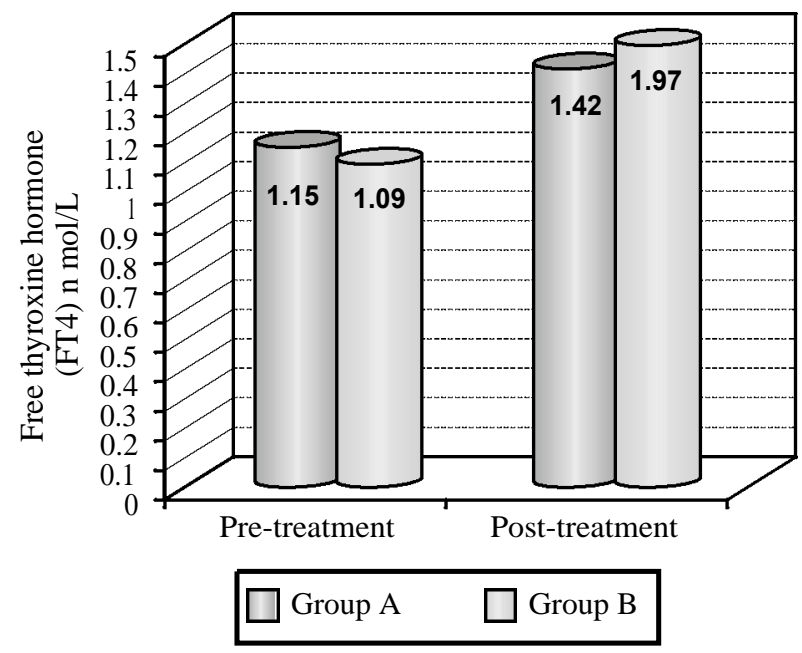

Fig. (10): Illustrates mean values of free thyroxine (FT 4) n $\mathrm{mol} / \mathrm{L}$ pre and post-treatment course for both groups $(\mathrm{A} \& \mathrm{~B})$.

\section{Discussion}

The results of this study showed a significant decrease in body weight, Body mass index, Waist hip ratio, total cholesterol, triglycerides, lowdensity lipoprotein, TSH with a significant increase in high-density lipoprotein, FT 3 and FT 4 after treatment in both groups. Yet, these changes were more pronounced and statistically significant in the study group when compared to the control. This means that whole body vibration training combined with low caloric diet program with thy- roxine tablets is much better than using low caloric diet program with thyroxine tablets only in treating obese postmenopausal women with hypothyroidism.

The results of this study came in agreement with (Bansal et al., 2015) who stated that "regular physical exercise can improve thyroid function and thus improve mental and physical status of hypothyroid patient and concomitantly decrease dose of thyroxine replacement therapy. It has a great impact on endocrine glands, it increases hormonal secretion of these glands in the circulating blood and thyroid is one of these glands".

The results of this study came in agreement with (Sakshi et al., 2019) who emphasized that "Regular exercise has both short-term and longterm benefits in menopausal women. Short term benefits include the management of menopausal symptoms, psychological distress, weight issues, immobility, and injuries".

The results of the present study agreed with (Gian et al., 2020) who reported that "Whole-body vibration (WBV) training has been established as a useful method to improve physical fitness in obese individuals. Vibration stimulus during half squatting might suggest a long-term effect of WBV on the endocrine system".

The results of the present study were confirmed by (Debmalya et al., 2016) who stated that "Hypothyroid obese postmenopausal women should make dietary changes for weight loss. Following a low caloric diet program can help to reduce body weight, decrease symptoms of thyroid dysfunction and decrease high cholesterol level in the blood. Weight loss by hypocaloric diet induces a significant change in serum FT 3 and TSH levels. It seems that even simple changes of lifestyle, characterized by increased physical activity and improvement in body composition and weight lead to an increase of metabolic rate and decrease high cholesterol level in blood".

(Rigamonti et al., 2018) explained that "Wholebody vibration (WBV) has become a common exercise used as alternative exercise modality to improve physical fitness and physical performance in obese and non-obese subjects. Several studies showed that long-term WBV practice has positive effects on body composition, bone mineral density, and heart rate (HR) variability. Moreover, it is well established that a single session of WBV positively influences the anabolic hormones in aged individuals and in obese subjects". This agreed with the results of the study. 
(Chi-Chang et al., 2018) demonstrated that "WBV may positively affect body weight, exercise performance, fatigue, fat accumulation and obesityassociated biochemical assessments in diet-induced obesity. It may be a potential sport for health promotion and have an anti-fatigue effect in preventing diet-induced obesity. For the future application with current results, the weight control, an important issue in modern society, could be intervened by diet management combined with vibration exercise, especially for obese population which couldn't tolerate the intensive aerobic exercise in the beginning". This came in agreement with the results of the current study.

(Wilms et al., 2017) reported that "WBV combined with endurance training could significantly increase resting energy expenditure for the improvement of body composition. Vibration exercise was attracted a lot of attention as an exercise modality, which elevates metabolic rate and activates muscular adaption that could be a potential method for weight reduction". This agreed with the results of the study.

\section{Summary:}

All these findings confirmed that, whole body vibration training combined with low caloric diet program with thyroxine tablets is much better than using low caloric diet program with thyroxine tablets in treating obese postmenopausal women with hypothyroidism. Thus, whole body vibration training has a great and beneficial effect on hypothyroidism in obese postmenopausal women. It gives amazing results and noticeable changes.

\section{References}

1- SWEENEY L.B., STEWART C., and GAITONDE D.Y.: Thyroiditis: an integrated approach. American Family Physician, 90 (6): 389-396, 2014.

2- ORT, BRUCE IAN BOGART and VICTORIA: Elsevier's integrated anatomy and embryology. Philadelphia, 3423, 2017.

3- RUHI CHARAK and RIMPY CHARAK: Oxidative Stress and Antioxidative Defence Mechanism in Patients with Hypothyroidism. International Journal of Advanced Research, 4 (7): 1077-1081, 2016

4- YAMADA M. and MORI M.: Mechanisms related to the pathophysiology and management of central hypothyroidism. Nat. Clin. Pract Endocrinol. Metab., 4 (12): 68394, 2018.

5- GARBER J.R., COBIN R.H., GHARIB H., HENNESSEY J.V., KLEIN I., MECHANICK J.I., PESSAH-POLLACK R. and SINGER P.A.: Clinical Practice Guidelines for Hypothyroidism in Adults.Thyroid., 22 (12): 1200-1235, 2015.

6- HUDZIK B. and ZUBELEWICZ-SZKODZINSKA B.: Radiocontrast-induced thyroid dysfunction: Is it common and what should we do about it?. Clin. Endocrinol. (Oxf), 80 (3): 322-327, 2014

7- DAVID Y. GAITONDE, M.D.; KEVIN D. ROWLEY, D.O. and LORI B. SWEENEY, M.D., DWIGHT D.: Eisenhower Army Medical Center, Fort Gordon, Georgia Am. Fam Physician, 1; 86 (3): 244-251, 2015.

8- NAZARPOUR S., RAMEZNI R., SIMBAR M. and AZIZI F.: Thyroid antibodies and the effect on pregnancy outcomes. Journal of Obstetrics and Gynecology, 36: 3-9, 2016.

9- RUGGE J.B., BOUGATSOS C. and CHOU R.: Screening and treatment of thyroid dysfunction: An evidence review for the U.S. Preventive services task force. Annals of Internal Medicine, 162: 35, 2015.

10- TAKAHASHI T.A. and JOHNSON K.M.: Menopause. The Medical clinics of North America, 99 (3): 521-34, 2015.

11- ELKINS, GARY R., FISHER, WILLIAM I., JOHNSON, AIMEE K., CARPENTER, JANET S. and KEITH, TIMOTHY Z.: Clinical hypnosis in the treatment of postmenopausal hot flashes: A randomized controlled trial. Menopause, Volume 20 - Issue 3 - p 291-298, 2019.

12- LAMBRINOUDAKI I., BRINCAT M. and EREL C.T.: EMAS Position Statement: Managing obese postmenopausal women. Maturitas, 66: 323-6, 2020.

13- MENON V.U., SUNDARAM K.R., UNNIKRISHNAN A.G., JAYAKUMAR R.V. and NAIR V.: Kumar High prevalence of undetected thyroid disorders in an iodine sufficient adult south Indian population. Jour Indian Med. Assoc., 107: 72-77, 2016.

14- LIZCANO F. and VARGAS D.: EID1-induces brown-like adipocyte traits in white 3T3-L1 pre-adipocytes. Biochemical and Biophysical Research Communications, 398 (2): 160-165, 2020

15- HESSION M., ROLLAND C., KULKARNI U., WISE A. and BROOM J.: Systematic review of randomized controlled trials of low-carbohydrate vs. low-fat/low-calorie diets in the management of obesity and its comorbidities.Obes. Rev., 10 (1): 36-50, 2020.

16-BANN D., HIRE D., MANINI T., COOPER R., BOTOSENEANU A. and McDERMOTT M.M.: Light Intensity Physical Activity and Sedentary Behavior in Relation to Body Mass Index and Grip Strength in Older Adults: Cross-Sectional Findings from the Lifestyle Interventions and Independence for Elders (LIFE) Study. Int. J. Obes. (Lond), 38 (1): 69-75, 2015.

17- LAU R.W., LIAO L-R., YU F., TEO T., CHUNG R.C. and PANG M.Y.: The effects of whole body vibration therapy on bone mineral density and leg muscle strength in older adults: A systematic review and meta-analysis. Clin. Rehabil., 25: 975-988, 2020.

18- CARDINALE M. and WAKELING J.: Whole body vibration exercise: Are vibration good for you? Br. J. Sports Med., 39: 585-589, 2018.

19- REHN B., LIDSTORM J., SKOGLUND J. and LINDSTORM B.: Effects on leg muscular performance from whole-body vibration exercise: Asystematic review. Scand J. Med. Sci. Sports, 17 (1): 2-11, 2020.

20- COUTO B.P., SILVA H.R., FILHO A.G., da SILVEIRA NEVES S.R., RAMOS M.G., SZMUCHROWSKI L.A 
and BARBOSA M.P.: Acute effects of resistance training with local vibration. Int. J. Sports Med., 34: 814-9, 2018.

21- LEE K., LEE S. and SONG C.: Whole body vibration training improves balance, muscle strength and glycosylated hemoglobin in elderly patients with diabetic neuropathy. The Tohoku Journal of Experimental Medicine, 231 (4): 305-314, 2020.

22- BANSAL A., KAUSHIK A., SINGH C.M., SHARMA V. and SINGH H.: The effect of regular physical exercise on the thyroid function of treated hypothyroid patients: An interventional study at a tertiary care center in Bastar region of India. Arch. Med. Health Sci., 3 (2): 244-6, 2015.

23- SAKSHI CHOPRA, K. APARNA SHARMA, PIYUSH RANJAN, ANITA MALHOTRA, NAVAL K. VIKRAM and ARCHANA KUMARI: Weight Management Module for Perimenopausal Women: A Practical Guide for Gynecologists. J. Midlife Health, 10 (4): 165-172, 2019.

24- GIAN PIETRO EMERENZIANI, DAFNE FERRARI, SIMONA FITTIPALDI, VIVIANA MARIA BIMONTE, CHIARA MAROCCO, EMANUELA A. GRECO, FABRIZIOPERRONI, SILVIA MIGLIACCIO, ANDREA LENZI, CARLO BALDARI and LAURA GUIDETTI:
Effects of Acute Whole-Body Vibration Practice on Maximal Fat Oxidation in Adult Obese Males: A Pilot Study.Randomized Controlled Trial: Obes. Facts, 13 (2): 117-129, 2020.

25- DEBMALYA SANYAL and MOUTUSI RAYCHAUDHURI: Hypothyroidism and obesity: An intriguing link. Indian J. Endocrinol. Metab., 20 (4): 554-557, 2016.

26- RIGAMONTI A.E., HAENELT M., BIDLINGMAIER M., De COL A., TAMINI S. and TRINGALI G.: Obese adolescents exhibit a constant ratio of GH isoforms after whole body vibration and maximal voluntary contractions. BMC Endocr. Disord., 18 (1): 96, 2018.

27- CHI-CHANG HUANG1, TZU-LING TSENG, WENCHING HUANG, YI-HSIU CHUNG, HSIAO-LI CHUANG and JYH-HORNG WU: Whole-Body Vibration Training Effects on Physical Performance and Obesity in Mice. Int. J. Med. Sci., 11 (12): 1218-122, 2018.

28- WILMS B., FRICK J., ERNST B., MUELLER R., WIRTH B. and SCHULTES B.: Whole body vibration added to endurance training in obese women - a pilot study. Int. J. Sports Med., 33 (9): 740-743, 2017.

\section{فعالية اهتزاز الجسيم كله على قصور الغدة الدرقية

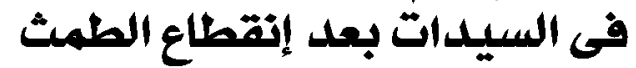

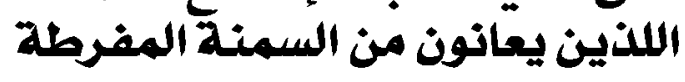

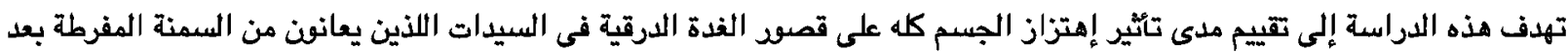

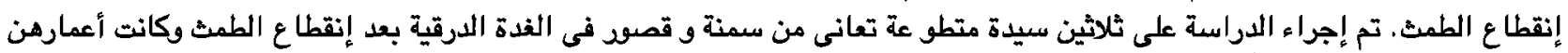

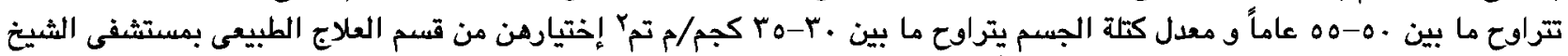

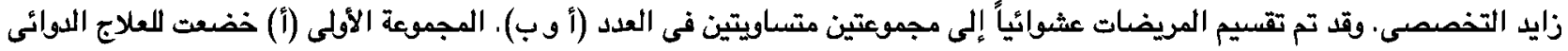

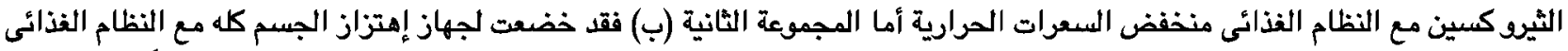

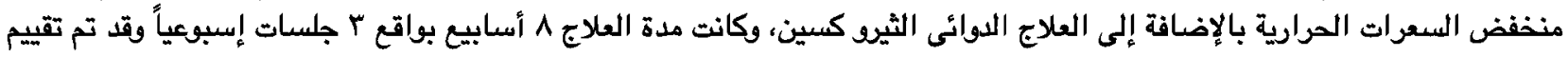

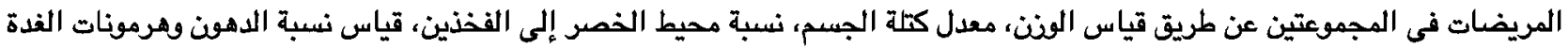

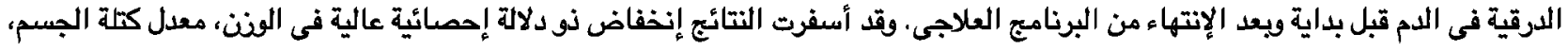

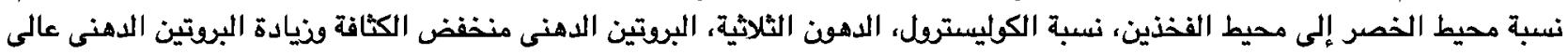

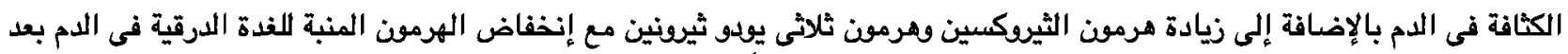

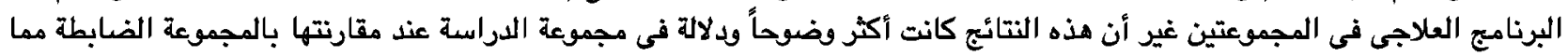

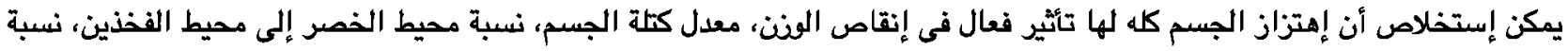

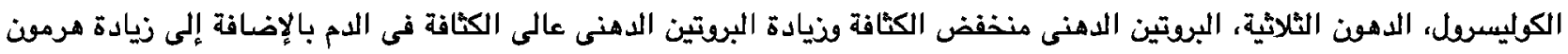

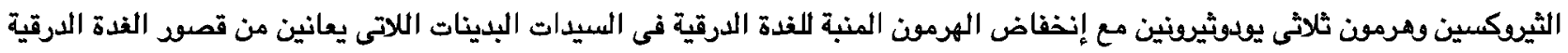

